\title{
Associations between chewing lice (Insecta, Phthiraptera) and albatrosses and petrels (Aves, Procellariiformes) collected in Brazil
}

\author{
Michel P. Valim ${ }^{1}$; Marcos A. Raposo ${ }^{2} \&$ Nicolau M. Serra-Freire ${ }^{1}$ \\ ${ }^{1}$ Laboratório de Ixodides, Departamento de Entomologia, Instituto Oswaldo Cruz. Avenida Brasil 4365, 21045-900 Rio de \\ Janeiro, Rio de Janeiro, Brasil. E-mail: mpvalim@hotmail.com \\ ${ }^{2}$ Setor de Ornitologia, Departamento de Vertebrados, Museu Nacional, Universidade Federal do Rio de Janeiro. Quinta da \\ Boa Vista, 20940-040 Rio de Janeiro, Rio de Janeiro, Brasil.
}

\begin{abstract}
Chewing lice were searched on 197 skins of 28 species of procellariiform birds collected in Brazil. A total of 38 species of lice were found on 112 skins belonging to 22 bird species. The lice were slide-mounted and identified. A list of lice species found and their host species is given and some host-louse associations are discussed under an evolutionary perspective.
\end{abstract}

KEY WORDS. Amblycera; ectoparasites; host-parasite relationship; Ischnocera.

\begin{abstract}
RESUMO. Associações entre malófagos (Insecta, Phthiraptera) e albatrozes e petréis (Aves, Procellariiformes) capturados no Brasil. Malófagos foram procurados em 197 peles de 28 espécies de aves Procellariiformes capturadas no Brasil. Um total de 38 espécies de piolhos foram encontradas em 112 peles pertencentes a 22 espécies de aves. Os piolhos foram montados em lâminas e identificados. Uma lista com as espécies de piolhos encontradas e seus hospedeiros é dada, além de algumas associações entre os piolhos e as aves serem discutidas sob uma perspectiva evolutiva.
\end{abstract}

PALAVRAS-CHAVE. Amblycera; ectoparasitos; Ischnocera; relação parasito-hospedeiro.

Albatrosses and petrels are primarily oceanic birds, representing almost the half of the bird biodiversity of the world oceans, a habitat where the avifaunal diversity is considerably reduced if compared with terrestrial habitats. Procellariiform biology and behaviour are unique among birds, as is their ectoparasitic fauna. Among the latter, feather mites and feather lice are the most abundant in numbers of species and of individuals (PRICE et al. 2003).

Chewing lice are wingless, dorso-ventrally flattened insects with chewing mouth parts, highly specialized to live on avian and mammalian hosts as permanent and obligate ectoparasites (Johnson \& Clayton 2003). Among all other ectoparasites, lice are the most host specific (SMITH 2001). Birds are parasitized by louse species belonging to two (Amblycera and Ischnocera) of the four suborders forming the insect order Phthiraptera.

The first two species of chewing lice from Procellariiformes were described by FABRICIUS (1775: 808) from a petrel and an albatross collected off the coast of Brazil by Joseph Banks, during Captain James Cook's first voyage around the world (PAlma 1991). One was "Pediculus Procellariae" [= Halipeurus procellariae (Fabricius, 1775)] from a "Brasiliae procellariis" and the other was "Pediculus Diomedeae" [=Paraclisis diomedeae (Fabricius, 1775)] from a "Brasiliae diomedeis". As many as 126 other louse species, still considered valid today, were described from albatrosses and petrels since 1775 .
Most of our knowledge about Brazilian bird lice is based on the work of Lindolpho Rocha Guimarães (1908-1998) who published many papers between 1936 and 1985. Guimarães published the original descriptions of 84 species of lice, with 73 of them still recognised as valid, a figure that earned him the $15^{\text {th }}$ place among the most productive phthirapterists in the world (PRICE et al. 2003). However, most of Guimarães work was on lice of terrestrial birds. Recently, some papers on the ecology and host relationships of Brazilian lice have been published (Oniki 1990, Roda \& Farias 1999, Freitas et al. 2002, Neves et al. 2000) but, again, they deal with terrestrial hosts only.

The 128 louse species of procellariiform birds are distributed over 117 host species, with one of the greatest ratios (430) of louse-host associations found among chewing lice (PRICE et al. 2003). All the louse species living on al batrosses and petrels are at present placed in a total of 16 genera, with 14 of these being exclusiveto the Procellariiformes. Many authors described lice from Procellariiformes in an ad hoc fashion, until Тном PSon (1938, 1939a, 1940) published the first papers dealing exclusively with these lice. Since then, many revisions have been produced, usually covering one genus each, and a complete overview of all procellariiform lice was published by TIMMERMANN (1965). Useful generic revisions have been published dealing with the following genera in the family Philopteridae (suborder Ischnocera): Trabeculus Rudow and Docophoroides Giglioli

Revista Brasileira de Zoologia 23 (4): 1111-1116, dezembro 2006 
by Timmermann (1959a, b); Halipeurus Thompson by Edwards (1961) and by Timmermann (1960, 1961b); Pseudonirmus Mjöberg, Episbates Thompson and Philoceanus Kellogg by Timmermann (1961a, c); Bedfordiella Thompson, Harrisoniella Bedford, Perineus Thompson and Naubates Bedford by PALMA \& PILGRIM (1983, 1984, 1988, 2002); Saemundssonia (Puffinoecus) by MARTIN-M ATEO (1996). Clay (1940) revised all the species which at present are placed in the genus Paraclisis Timmermann, but which were included in Perineus at that time. Among the Menoponidae (suborder Amblycera), the genera Austromenopon Bedford and Longimenopon Thompson have been revised by PRICE \& CLAY (1972) and by Timmermann (1957), respectively. Price et al. (2003) published the most recent and comprehensive checklist of bird chewing lice with their host associations.

The purpose of this paper is to contribute to the knowledge of feather lice found on species of procellariiform birds in Brazil and to discuss some of the evolutionary implications of the host-louse associations under a phylogenetic perspective.

\section{MATERIAL AND METHODS}

Lice were collected from 112 bird skins (57\%) belonging to 22 species, from a total of 197 skins examined belonging to 28 species of Procellariiformes from Brazil, and deposited in the Ornithological collection of the Museu Nacional, Universidade Federal do Rio de Janeiro. The bird species studied with louse-negative results were: Diomedea exulans Linnaeus, 1758 [Diomedeidae]; A phrodroma brevirostris (Lesson, 1831); Pterodroma lessonii (Garnot, 1826); Procellaria cinerea Gmelin, 1789; Puffinus assimilis Gould, 1838 [Procellariidae] and Oceanodroma castro (Harcourt, 1851) [Hydrobatidae].

The collecting technique used was that published by HopkIns (1949). After their removal from the skins, lice were slide-mounted following the technique of PALMA (1978). Some samples were not identified to species because of the absence of one of the sexes, or the lack of adult lice. We regard as stragglers those lice which have changed hosts by natural means, while contaminants are lice which have been transferred from one host species to another by human agency (PILGRIM \& PALMA 1982). Louse nomenclature follows that used by PRICE et al. (2003) and the bird names follow REMSEN et al. (2004). The evolutionary inferences are based on the phylogeny proposed by Penhallurick \& Wink (2004).

\section{RESULTS}

A total of 33 species of lice were identified, with a further 5 records left at the genus level (species under study), totalizing 38 species.

The lice species recorded were distributed in two suborders and two families. The suborder Amblycera Kellogg is represented by the family Menoponidae Mjöberg and species: Ancistrona vagelli (Fabricius, 1787); Austromenopon brevifimbriatum (Piaget, 1880); A. echinatum Edwards, 1960; A. edwardsi Price \& Clay, 1972; A. navigans (Kellogg, 1896); A. ossifragae (Eichler,
1949); A. paululum (Kellogg \& Chapman, 1899); A. popellus (Piaget, 1890); A. stammeri Timmermann, 1959; Austromenopon sp.; and Longimenopon galeatum Timmermann, 1957.

The species of the suborder Ischnocera Kellogg, family Philopteridae Burmeister were: Docophoroides brevis (Dufour, 1835); D. harrisoni Waterston, 1917; D. murphyi (Kellogg, 1914); D. simplex (Waterston, 1914); Halipeurus (Halipeurus) abnormis (Piaget, 1885); H. (Halipeurus) diversus (Kellogg, 1896); H. (Halipeurus) procellariae; H. (Halipeurus) turtur Edwards, 1961; H. (Synnautes) pelagicus (Denny, 1842); Naubates (Naubates) fuliginosus (Taschenberg, 1882); N. (Guenterion) prioni (Enderlein, 1909); Naubates sp.; Paraclisis diomedeae; P. obscura (Rudow, 1869); Philoceanus fasciatus (Carriker, 1958); P. robertsi (Clay, 1940); Pseudonirmus gurlti (Taschenberg, 1882); Saemundssonia (Saemundssonia) bicolor (Rudow, 1870); S. (Saemundssonia) stammeri Timmermann, 1959; S. (Saemundssonia) desolata Timmermann, 1959; S. (Puffinoecus) peusi (Eichler, 1949); Saemundssonia sp.; Trabeculus aviator (Evans, 1912); T. hexakon (Waterston, 1914); T. schillingi Rudow, 1866; Trabeculus sp.

Species of chewing lice and birds found in associations are shown in the table I.

\section{DISCUSSION}

Most of the records and host-louse associations listed in the table I agree with previous studies by THOMPSON (1939b), WARD \& Downey (1973), Pilgrim \& Palma (1982), PALMa \& HoRning (2002) and PRICE et al. (2003) for regional and world lists.

On members of the albatross family Diomedeidae, we found the genera Docophoroides (three species) and Paraclisis (one species), both belonging to the louse family Philopteridae, which corroborate records by THOMPSON (1939b), WARD \& Downey (1973), Pilgrim \& Palma (1982), and Palma \& Horning (2002). We were not able to find any specimen of the genera Episbates, Harrisoniella or Perineus, which are also characteristic ectoparasites on members of the Diomedeidae (PRICE et al . 2003: 368). Also, on the Diomedeidae, we found one species of the genus Austromenopon (Family Menoponidae), the only genus of the suborder Amblycera with species parasitic on al batrosses (Thompson 1939b, Ward \& Downey 1973, Pilgrim \& Palma 1982, Price et al. 2003).

Among petrels and shearwaters (Procellariidae), we found records that agree with those published by THOMPSON (1939b), Ward \& Downey (1973), Pilgrim \& Palma (1982), and Palma \& HoRning (2002). The only philopterid genus not recorded in our work was Bedfordiella, a monotypic genus exclusive to the Kerguelen petrel (PALma \& PILgRim 1983). The genera of Menoponidae (Amblycera) found on the Procellariidae also agree with literature records (PILgRIM \& Palma 1982, Palma \& Horning 2002, Price et al. 2003). Our finding of Longimenopon is a rare occurrence, because of the special microhabitat occupied by these lice, inside the calamus of primary feathers.

In the family Hydrobatidae (storm petrels), our records also agree with those in Pilgrim \& Palma (1982) and Price et al.

Revista Brasileira de Zoologia 23 (4): 1111-1116, dezembro 2006 
Table I. The lice species (lines) and the hosts (birds species on columns) found in association. The " $\mathrm{X}$ " represents the positive records and the "?" the possible stragglers or contaminants discussed in the text.

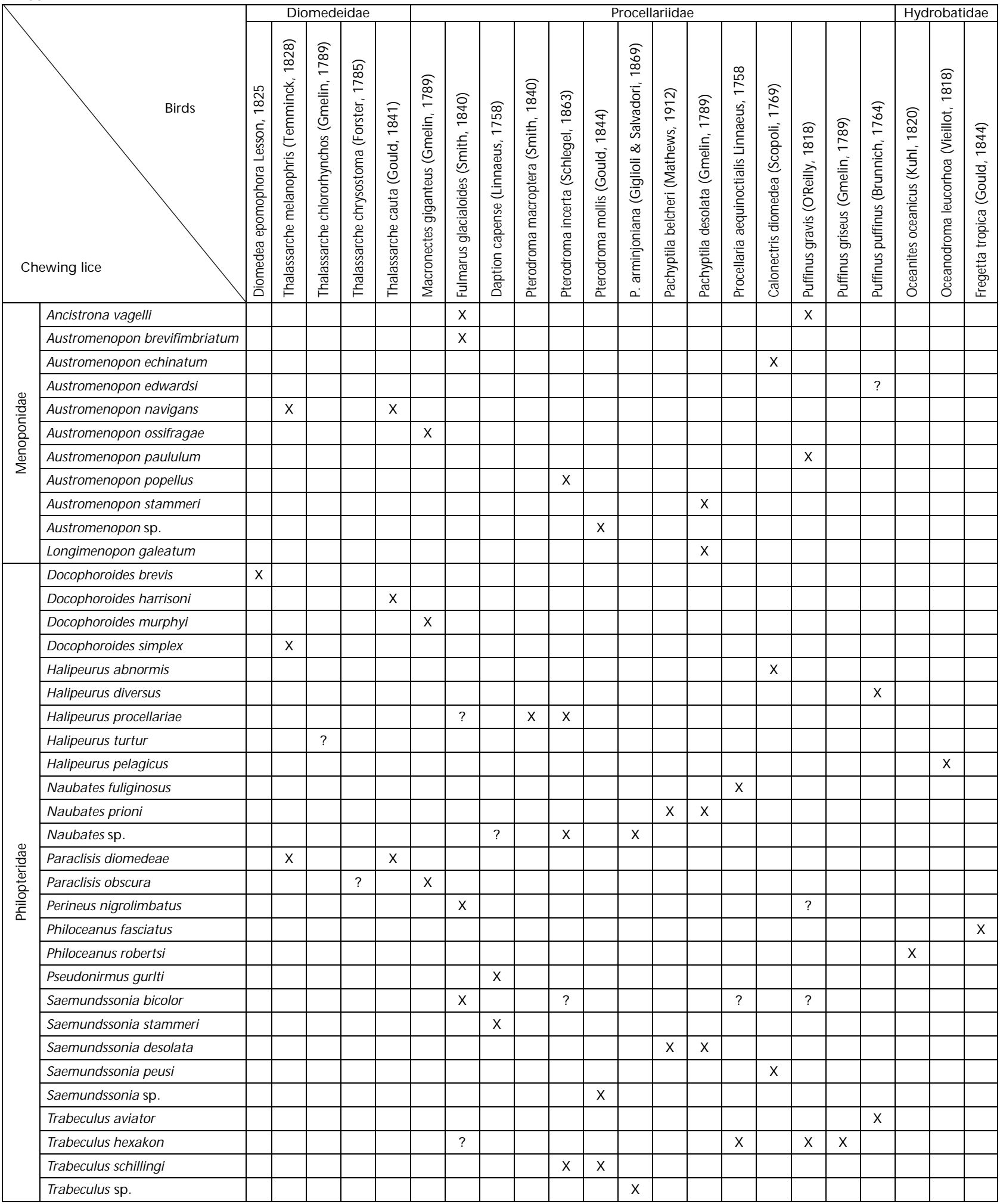


(2003). Among the skins of Brazilian storm petrels examined, we were unable to find any louse of the genera Saemundssonia (Philopteridae), Austromenopon, or Longimenopon (Menoponidae), all known to include species parasitic on hydrobatid hosts (PRICE et al. 2003).

Some of these associations point clearly to a coevolution of these parasites with various taxa of Procellariiformes, indicating a potential use of louse species in future cladistic analyses of the bird order. At the host subfamily level it can be exemplified by species such as the louse Austromenopon navigans and the genus Docophoroides that were clearly related to the Diomedeinae, a monophyletic group corroborated by Penhallurick \& Wink (2004). At the host genus level, the louse Trabeculus schillingi occurs only in Pterodroma. The louse genus Philoceanus is associated with the family Hydrobatidae only and, in this study, it was found in Ocenites oceanicus and Fregetta tropica. Some genera, for instance Saemundssonia and Trabeculus, were found in our study exclusively associated with the Procellariidae. It is worth mentioning that the clade that comprises the Procellariidae, as proposed by Penhallurick \& Wink (2004), excludes the genus Pachyptila, considered by them as incertae sedis. The clade formed by the species of Pachyptila hosts the lice Naubates prioni and Saemundssonia desolata.

On the other hand, a comparison of the distribution of the lice with the procellariform phylogeny shows some interesting aspect on the evolutionary trend of the lice. Species of the genera Austromenopon, D ocophoroides and Paraclisis that are parasitic on the Diomedeinae may, after a proper phylogenetic analysis, demonstrate some degree of dispersion in the direction of Macronectes giganteus (Procellariidae) that al so hosts those louse genera. This phenomenon could point to some degree of convergence in habits or habitat of both bird groups.

A comparison of the distribution of louse species on Procellariiformes with the phylogeny of this order can therefore be used as a more testable criterium to the definition of what can be considered contaminants or stragglers, because both are often expected when lice are collected from bird skins kept in museums. New occurrences of the same parasite in close host species could be treated as possible new records, but they still need to be confirmed by further sampling. Other unexpected new records should be considered as most likely contaminants.

One example of this approach is the record of Halipeurus (Halipeurus) turtur from Thalassarche chlororhynchos. It is here regarded as a possible straggler or contaminant, given the high degree of specificity shown by species of the genus Halipeurus with the families Procellariidae and Hydrobatidae (EDwARDS 1961, PRICE et al. 2003), but it is interesting to draw attention to the fact that Penhallurick \& Wink (2004) considered the Hydrobatidae and the Procellariidae as polyphyletic groups. This is also the case of our record of Paraclisis obscura on Thalassarche chrysostoma, given the high degree of host-specificity shown by P. obscura with species of Macronectes only (PILGrim \& Palma 1982, PrICE et al. 2003).

Revista Brasileira de Zoologia 23 (4): 1111-1116, dezembro 2006
Other records that could be attributed to contamination or straggling are: Perineus nigrolimbatus, (a louse associated with Fulmarus) from Puffinus gravis, as no species of Puffinus is a natural host to any species of Perineus, and Trabeculus hexakon (a louse species associated with the genera Procellaria, Puffinus and Pterodroma) from Fulmarus glacialoides, because no species of Fulmarus is a natural host to any species of Trabeculus. The natural and regular host species for Perineus nigrolimbatus and Trabeculus hexakon were taken from PILGRIM \& PALMA 1982 and PrICE et al. 2003 as shown in the table I.

The record of Halipeurus (Halipeurus) procellariae from Fulmarus glacialoides was not expected because no species of Fulmarus has ever been reported as a natural host to any species of Halipeurus. This is clearly a case of straggling or contamination.

Furthermore, the unexpected records of Saemundssonia bicolor from Pterodroma incerta, Procellaria aequinoctialis and Puffinus gravis (all based on one specimen) should also be interpreted as stragglers or contaminants (Foster et al. 1996, PrICE et al. 2003), although they are all present in the monophyletic Procellariidae of Penhallurick \& Wink (2004). Austromenopon edwardsi from Puffinus puffinus should also be regarded as straggler or contaminant, but it is important to mention that this species has al ready been found in other species of Puffinus (P. heinrothi Reichenov, P. Iherminieri Lesson and P. navitatis Streets). The lack of a natural host-louse association between Saemundssonia bicolor and Pterodroma incerta, Procellaria aequinoctialis \& Puffinus gravis has al ready been tested and shown to be negative by PaLma $\&$ PILGRIM (1982), Foster et al. (1996), and several other studies.

Many chewing lice cannot be identified to species when only immature stages or one sex of the adult stage is found. In addition, the probability of finding both sexes on museum skins is low because handling and storage practices causes loss of specimens. Therefore, chewing lice on four skin samples could only be identified to the genus level as shown in the table I. These specimens are included in this study because this information contributes to our current knowledge of bird-louse relationships. For example, it was confirmed that louse specimens identified only to genera, and belonging to Naubates, Austromenopon, Saemundssonia, and Trabeculus, have an association with the avian family Procellariidae. Other studies (PRICE et al. 2003) have shown that only one species of the four genera mentioned above has been collected on a unique species within the Procellariidae. Therefore, it can be suggested that the unidentified lice specimens are actually N. damma Timmermann, 1961 (on P. arminjoniana) and N. pterodromi Bedford, 1930 (on P. incerta), Austromenpon popellus, Saemundssonia enderleini (Eichler, 1949), and Trabeculus fuscoclypeatus (Johnson \& Harrison, 1912). However, since we cannot confirm morphologically these specimens to species, we decided to be cautious and merely report them to the level of genera. The finding of Naubates sp. in a skin of Daption capensis is a true case of contamination. 
Museum collections are still a useful source of material when access to live or freshly killed birds is not possible. The host-louse associations presented here will facilitate the addition of future new records of procellariiform lice from field collections, as well as to correct possible errors. This list is by no means complete, as we are well aware that preserved museum skins carry only a fraction of all the lice present on the bird at the time of death. For example, many procellariiform birds are collected dead on beaches, after having been washed by sea waves and deposited on the sand, a process that is known to remove lice from the plumage (Ricardo L. Palma, Museum of New Zealand Te Papa Tongarewa, pers. comm. 2004). Judging from the large number of host-louse associations published for all species of Procellariiformes and the results of this paper, future collecting from al batrosses and petrels in Brazil will produce a great number of additional louse records, thus contributing to the understanding of the evolution of this bird order. A cladistic analysis of the Procellariiformes, based on their lice as characters, will eventually be possible with the increase of knowledge of these host-louse associations.

\section{ACKNOWLEDGEMENTS}

To the Fundação Carlos Chagas Filho de Amparo à Pesquisa do Estado do Rio de Janeiro (FAPERJ) for support to M.A. Raposo (proc. Instalação E-26/ 170.871/2003 and Primeiros Projetos E-26/ 170.642/2004). To Gabriel Mejdalani and Jorge Bruno Nacinovic for their review of the final version, and to Ricardo L. Palma (Curator of Insects, Museum of New Zealand Te Papa Tongarewa, Wellington) for his critical review of the original Portuguese manuscript, for translating it into English and for reviewing the final draft.

\section{REFERENCES}

Clay, T. 1940. Anoplura. British Graham Land Expedition 1934-37 Scientific Reports, London, 1 (5): 295-318.

EDWARDS, R.L. 1961. Studies of the Philopteridae (Mallophaga) from the birds of the order Procellariformes [sic]. 1. The genus Halipeurus. Journal of Parasitology, Lawrence, 47 (1): 125157.

FABRICIUS, J.C. 1775. Systema Entomologiae, sistens insectorum, classes, ordines, genera, species, adiectissynonymis, locis, descriptionibus, observationibus. Flensburgi, Officina Libraria Kortii, XXXII+832p.

Foster, G.W.; J.M. Kinsella; R.D. Price; J.W. Mertins \& D.J. ForRESTER. 1996. Parasitic helminths and arthropods of Greater Shearwaters (Puffinus gravis) from Florida. Journal of the Helminthological Society of Washington, Lawrence, 63 (1): 83-88.

Freitas, M.F.L.; M.C.N Botelho; A.S. Leite; V.S. Magalhães; A.E. Sobrinho; R.A. Oliveira; M.H.C.C. Oliveira \& J.B. Oliveira. 2002. Ectoparasitos de aves silvestres mantidas em cativeiro no estado de Pernambuco, Brasil. Entomologia y Vectores,
Salta, 9 (1): 25-33.

Hopkins, G.H.E. 1949. The host-associations of the lice of mammals. Proceedings of the Zoological Society of London, London, 119: 387-604.

Johnson, K.P. \& D.H. Clayton. 2003. The biology, ecology, and evolution of chewing lice, p. 449-476. In: R.D. PRICE; R.A. Hellenthal; R.L. Palma; K.P. Johnson \& D.H. Clayton (Eds). The chewing lice: world checklist and biological overview. Illinois, Illinois Natural History Survey Special Publication, 24+501p.

Martin-Mateo, M.P. 1996. Species of the genus Puffinoecus Eichler, 1949 (Mallophaga: Philopteridae) parasites on Shearwaters (Aves: Procellariidae). Research and Reviews in Parasitology, Barcelona, 56 (1): 49-62.

Neves, R.L.; A.M.I. Farias; W.R. Telino-Júnior; M. Arzua; M.C.N. Botelho \& M.C.A. LımA. 2000. Ectoparasitismo em aves silvestres (Passeriformes - Emberizidae) de Mata Atlântica, I garassu, Pernambuco. Melopsittacus, Belo Horizonte, 3 (2): 64-71.

ONIKI, Y. 1990. Survey of lice (Mallophaga) and some remarks on their life cycles on birds at Balbina, Amazonas, Brazil. Revista Brasileira de Biologia, Rio de Janeiro, 50 (3): 615617.

PALMA, R.L. 1978. Slide-mounting of Lice: a detailed description of the Canada Balsam technique. New Zealand Entomologist, Nelson, 6 (4): 432-436.

Palma, R.L. 1991. Two bird lice (Insecta: Phthiraptera) collected during Captain Cook's 2nd voyage around the world. Archives of Natural History, London, 18 (2): 237-247.

PaLma, R.L. \& D.S. Horning. 2002. Thelice (Insecta: Phthiraptera) from Macquarie Island. ANARE Research Notes, Kingston, 105: 1-27.

Palma, R.L. \& R.L.C. Pilgrim. 1983. The genus Bedfordiella (Mallophaga: Philopteridae) and a note on the lice from the Kerguelen petrel (Pterodroma brevirostris). National Museum of New Zealand Records, Wellington, 2 (13): 145-150.

Palma, R.L. \& R.L.C. PILgRim. 1984. A revision of the genus Harrisoniella (Mallophaga: Philopteridae). New Zealand Journal of Zoology, Wellington, 11 (2): 145-166.

Palma, R.L. \& R.L.C. PILGRIM. 1988. A revision of the genus Perineus (Phthiraptera: Philopteridae). New Zealand Journal of Zoology, Wellington, 14 (4): 563-586.

PaLmA, R.L. \& R.L.C. PILgrim . 2002. A revision of the genus Naubates (Insecta: Phthiraptera: Philopteridae). Journal of the Royal Society of New Zealand, Wellington, 32 (1): 7-60.

Pilgrim, R.L.C. \& R.L. Palma. 1982. A list of the chewing lice (Insecta: Mallophaga) from birds in New Zealand. National Museum of New Zealand (Miscellaneous Series), Wellington, 6: 1-32.

Penhallurick, J. \& M. Wink. 2004. Analysis of the taxonomy and the nomenclature of the Procellariiformes based on complete nucleotide sequences of the mitochondrial citochrome b gene. Emu, Collingwood, 104: 125-147. 
PrICE, R.D. \& T. CLAY. 1972. A review of the genus Austromenopon (Mallophaga: Menoponidae) from the Procellariiformes. Annals of the Entomological Society of America, College Park, 65 (2): 487-540.

Price, R.D.; R.A. Hellenthal \& R.L. Palma. 2003. World checklist of chewing lice with host associations and keys to families and genera, p. 1-448. In: R.D. Price; R.A. Hellenthal; R.L. PALMA; K.P. Johnson \& D.H. CLAYTON (Eds). The chewing lice: world checklist and biological overview. Illinois, Illinois Natural History Survey Special Publication, 24+501p.

Remsen, J.V.; A. Jaramillo; M. Nores; J.F. Pacheco; M.B. Robbins; T.S. Schulenberg; F.G. Stiles; J.M.C. Silva; D.F. Stotz \& K.J. Zimmer. 2004. A classification of the bird species of South America. American Ornithologists Union. Available in the World Wide Web at http://www.museum.Isu.edu/-Remsen/ SACCBaseline.html [accessed in 15.II.2005].

RodA, S.A. \& A.M.I. FARIAS. 1999. Wild birds infested by Phthiraptera (Insecta) in the North Forest Zonethe Pernambuco, Brazil. Revista Brasileira de Zoologia, Curitiba, 16 (3): 871-878.

SMITH, V.S. 2001. Avian louse phylogeny (Phthiraptera: Ischnocera): a cladistic study based on morphology. Zoological Journal of the Linnean Society, London, 132: 81-144.

Thompson, G.B. 1938. The lice of Petrels - Part I. Annals and Magazine of Natural History (Series 11), London, 2: 481-493.

Thompson, G.B. 1939a. The lice of Petrels - Part II. The elongate forms. Annals and Magazine of Natural History (Series 11), London, 3: 114-119.

Thompson, G.B. 1939b. A list of the type hosts of the Mallophaga and the lice described from them. Annals and Magazine of Natural History (Series 11), London, 3: 241-252.

Thompson, G.B. 1940. The lice of Petrels - Part III. Annals and Magazine of Natural History (Series 11), London, 6: 103111.

Received in 20.IV.2006; accepted in 30.X.2006.
Timmermann, G. 1957. Mallophaga from Tristan da Cunha. Part II. Some remarks on the genus Longimenopon Thompson, 1948. Results of the Norwegian Scientific Expedition to Tristan da Cunha, Oslo, (41): 7-12.

Timmermann, G. 1959a. Taxonomieund hospitale Verbreitung der Mallophagengattung Trabeculus Rudow, 1866. Zeitschrift für Parasitenkunde, Berlin, 19: 485-502.

Timmermann, G. 1959b. Zur Kenntnis der Gattung Docophoroides Giglioli, 1864 (Insecta, Mallophaga). Mitteilungen ausdem Zoologischen Museum in Berlin, Berlin, 35 (1): 57-72.

TimmermanN, G. 1960. Gruppen-Revisionen bei Mallophagen. II. Genus Halipeurus Thompson 1936. 1. Teil: DieHalipeurusArten der "gadfly-petrels" (Genera Pterodroma und Bulweria). Zeitschrift für Parasitenkunde, Berlin, 20: 317-334.

Timmermann, G. 1961a. Gruppen-Revisionen bei Mallophagen. IV. Genera Pseudonirmus Mjöberg, 1910, Bedfordiella Thompson, 1937, und Episbates Harrison, 1935. Zeitschrift für Parasitenkunde, Berlin, 21: 30-45.

Timmermann, G. 1961b. Gruppen-Revisionen bei Mallophagen. II. Genus Halipeurus Thompson 1936. 2. Teil: DieHalipeurusArten der Wasserscherer (Puffininae), Sturmtaucher (Pelecanoididae) und Sturmschwalben (Hydrobatidae). Zeitschrift für Parasitenkunde, Berlin, 20: 401-419.

TimmermanN, G. 1961c. Gruppen-Revisionen bei Mallophagen. III. Genus Philoceanus Kellogg, 1903. Zeitschrift für Parasitenkunde, Berlin, 20: 525-537.

Timmermann, G. 1965. Die Federlingsfauna der Sturmvögel und diePhylogenesedes procellariiformen Vogelstammes. Abhandlungen und Verhandlungen des Naturwissenschaftlichen Vereins in Hamburg N. F., Hamburg, 8 (Suppl.): 1-245.

WARD, R.A. \& J.C. DowneY. 1973. Checklist of the Mallophaga of Midway Atoll, Pacific Ocean. Journal of Medical Entomology, Lanham, 10 (4): 391-396. 